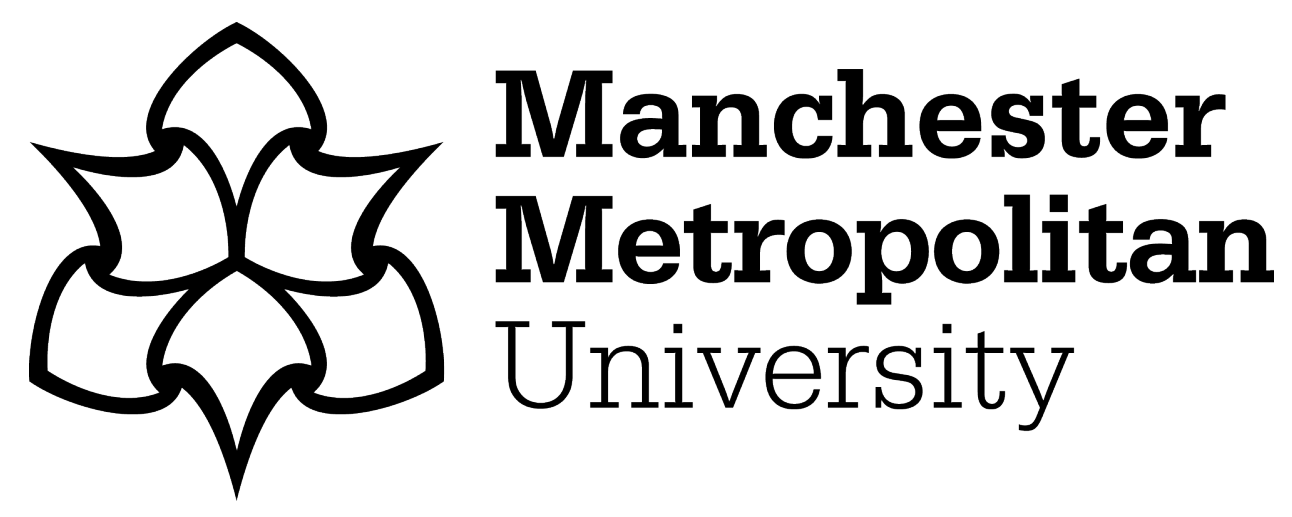

Whittle, ST and Turner, L (2016) Queer Europe: new normative values for global LGBT law. In: Transgender and Intersex: theoretical, practical, and artistic perspectives. Palgrave Macmillan, pp. 29-65. ISBN 1349713252

Downloaded from: https://e-space.mmu.ac.uk/620620/

Publisher: Palgrave Macmillan

DOI: https://doi.org/10.1057/978-1-349-71325-7_2

Please cite the published version 


\section{Queer Europe: New Normative Values for Global LGBT Law ${ }^{1}$}

(C2016 Stephen Whittle (Manchester Law School, Manchester Metropolitan) and Lewis Turner (ex. Lancaster University)

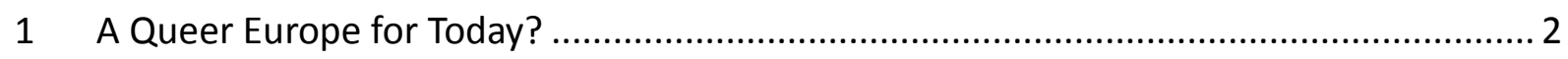

2 Europe's Historical and Legal Perceptions of Sex and Gender ....................................... 3

2.1 Roman Law and the Determination of Legal Sex................................................. 7

2.2 The Common Law and the Determination of Legal Sex ......................................... 8

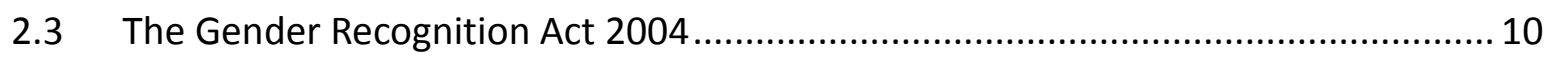

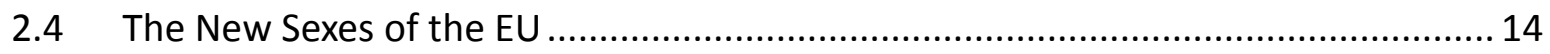

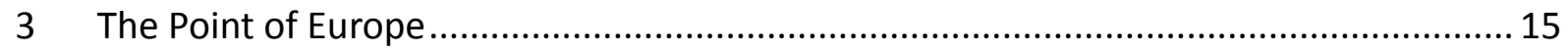

3.1 The Council of Europe and the European Convention on Human Rights.................. 17

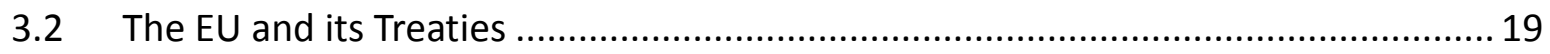

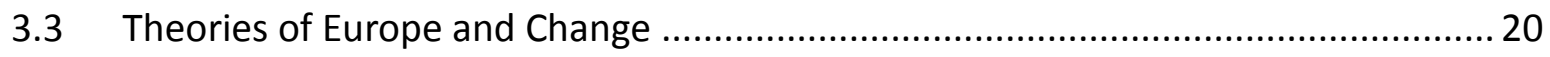

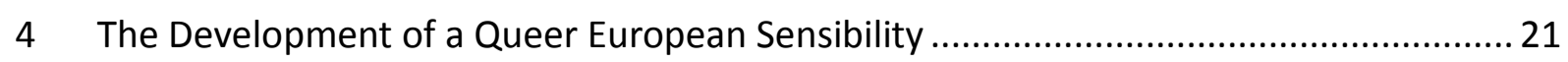

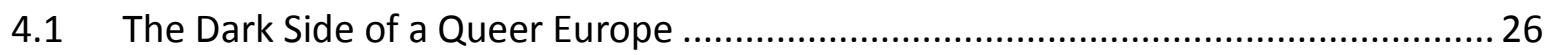

4.2 A Normative and Ethical Queer Europe: The Treaty of Lisbon ............................... 30

Abstract: This article considers how the new 'Europes' of the European Union (EU) and the Council of Europe ( $\mathrm{COE}$ ) have tackled the problems of a historical Judeo-Christian based legal framework in which lesbian, gay, bisexual and transgender people (LGBT) were persecuted within nation states. It addresses the late medieval and early modern developments which took the values of what was initially Church religious law and transferred these into state and secular laws; laws which were to prosecute and for many years, judicially kill LGBT people. It also looks at the rare cases where nation states did not embody these former religious rules, and why, and to what extent that protected LGBT people.

The article also reviews the differences, historically, in how the two legal systems in Europe, the Civil Codified 'Roman' Law of Continental Europe and the Common Law of Great Britain, addressed the determination of a person's sex for the purposes of legal decision making and

1 This chapter is laid out for sharing on Research Gate, and does not match the published layout. The original publication is Chapter 2 in Stefan Horlacher (ed) 2016, Transgender and Intersex: Theoretical, Practical, and Artistic Perspectives New York, Palgrave Macmillan. 
property inheritance. This was important for determining whether or not a person was committing a criminal offence by their sexual activity.

The article then discusses the response of European nations to the Nazi genocide of World War II, and the development of the two parallel European jurisdictions, one economic, one based in Human Rights. These jurisdictions have created a new moral sensibility, a standard by which the law of Europe is in itself to be judged. A new 'rule of law' which has contributed to a social as well as a legal framework in which LGBT people's rights have been increasingly recognized. The article contrasts this with the history of national persecutions of LGBT people, and discusses how the new versions of Europe have led to a process of creating normative and ethical law in which LGBT rights are natural and given.

\section{A Queer Europe for Today?}

Today's Europe is a mass of contrasts. There are over 800 million citizens in what is the larger European alliance; those states which are members of the CoE and are signatories to the European Convention on Human Rights (CoE 1950). The population of this larger Europe inhabits a huge spread and range of land types. It is the Europe which travels from the port of Lisbon on the sun bathed Atlantic shores of south of Portugal over 11,000 kilometers to the Arctic climate of Provideniya on the furthest Northeastern reaches of Russia, the point at which the Bering strait provides the doorway to Alaska; as queer theorists, Downing and Gillet put it:

"Whichever way you look at it, 'Europe' is a queer kettle of fish" (Downing and Gillett 1).

Lisbon and Provideniya demonstrate the contrasts and challenges in which the Human Rights bound by the Convention are played out. Lisbon is the eleventh most populous urban area in the European Union (EU). Its administration encompasses more than three million urban and semi-urban contemporary Europhile residents, many in modern, privately owned, recently built, state of the art, solar powered apartments. Politically aware, they are modern republicans, working in a diversified yet increasingly service-based economy. But, hit hard by the 2008 financial crisis, Portugal's unemployment rate rose from 7.3 per cent in June 2008, to 16.9 per cent in January 2013 (Trading Economics). 
In contrast, the Russian port of Provideniya in the Chukotka region has a population primarily made up of the indigenous Yupik, a group of people more commonly seen in central Alaska. Originally a native Siberian fishing village, it grew rapidly when oil was discovered in the 1970 s. But now employment has declined even more rapidly than in Lisbon, and since the departure of the oil industry, the population has fallen from over five thousand in the 1989 census to less than two thousand in 2010. Providenya's people live in Soviet-style, grim apartment buildings of the type prevalent in many towns and cities of the former Soviet Union countries. The small population struggles to survive on what little employment there is left in transport, shipping, and the town's seaport. You would struggle to find anywhere less modern and less wealthy in Europe.

Lisbon is now a truly modern European city, and in recent years, there, as in much of the rest of Western Europe, we have seen a massive change in the social recognition of the rights of LGBT people. More importantly though, is that throughout this huge, complex, and truly international Europe, from modern Lisbon to ancient Provideniya, the principles have been established in Europe's laws that, regardless of what certain eastern European governments may prefer, LGBT people have a right to be equal, to have their relationships recognized, and to live emotional public lives without punishment or discrimination.

This paper addresses how that change has come about, what that change says about the modern European understanding of the rule of law, and suggests that it provides a model; a moral compass for other nations moving forward to give new rights, or protect old rights, for all sorts of social minority groups. Nowhere is this more clearly seen than in recent advances and changes to laws concerning the legal recognition of the gender (sex) of transsexual and transgender (trans) people in Europe.

\section{Europe's Historical and Legal Perceptions of Sex and Gender}

The question of legal sex or gender has become increasingly irrelevant in contemporary Western European cultures. With the recognition of equal opportunities and rights for women and men, there are very few circumstances left where the sex or gender of an individual might now be considered legally germane. There have been significant changes, in the last twenty 
years, to various parts of European and English law to ensure its gender neutrality. ${ }^{2}$ However, this is a very new approach. The history of jurisprudence has shown the state to have been overly concerned with the individual, their sex determination and their sexual activity.

By reviewing the background of the United Kingdom's Gender Recognition Act 2004 it is possible to see why a change of 'legal gender' would end up becoming the primary mechanism of changing personal 'sex', not only in the UK, but throughout most of Europe. Recent legislation in many European states, following the decision of the European Court of Human Rights (ECtHR) in the cases of Goodwin $v$ the United Kingdom and I $v$ the United Kingdom (both $2002)^{3}$ has had to both accommodate the new cultural concept of gender identity alongside the, to date, legal mechanisms that record the biological sex of a child at birth. Throughout history, it has been the determination of apparent biological sex-what the midwife seeswhich produces the text on the child's birth certificate. Despite the warning on the UK birth certificate to the effect that it should not be used as a form of identification, the birth certificate is still a requirement by many parties including parts of government when requesting proof of identity. The birth certificate and its sex designator, $m$ or $f$, which in the UK after the English case of Corbett $v$ Corbett $(1970)^{4}$ remained, it seemed, set in stone, meant that the sex named at birth consequently disabled trans people from attempting to access or actually accessing many jobs or services.

For a variety of reasons, the historiography and the function of 'sex' in the West reiterated the law's primary concern with the ownership and distribution of property and wealth. The essential desire of the law to confirm ownership was invariably premised on male succession. It was within that framework that, at times, the law needed to determine a person's 'sex'. There have always been moments when the midwife did indeed lift the baby and the question of whether there is a penis or not has been problematic (see Whittle 2002). Even to this day,

2 E.g. the Sexual Offences Act 2003 achieves gender neutrality by ensuring that offences are relevant only to the body parts assaulted-and for example, the main offence of rape is now gender neutral as far as the victim is concerned. And though the perpetrator is required to have a penis, the similar offence of Assault by Penetration, which is completely gender neutral, carries the same levels of punishment.

3 Christine Goodwin v. UK Government, [2002] European Court Of Human Rights (application No. 28957/95) and I v. UK Government, [2002] European Court Of Human Rights (Application No. 25608/94).

4 Corbett v. Corbett [1970] 2 All England Reports. 33, 48; [1970] 2 Weekly Law Reports. 1306-24. 
the question of the size of the penis continues to raise the matter of what legal sex a person is to the forefront of jurisprudence. ${ }^{5}$

Legal systems have historically addressed the clarification of a person's sex through various different principles. The possibility of a person being of both or neither sex was so problematic in the determination of property law that the primary principle has been to place the person in one category or the other. At the core of the debate the question has been, if a person's sex has to be determined, then what method will be used to distinguish the features which will be used to determine which one of the two sexes is dominant when a person's sex is not clear?

The debate that took place around the hermaphrodite body was not necessarily the hermaphrodite we would recognize today. Historically the hermaphrodite body was defined by physicians and lawyers or magistrates through an examination of the apparent extent of a person's external characteristics, for example whether an appendage is long enough to be a penis, or short enough to be a clitoris. Secondary sex characteristics, for example the pattern of body hair, the extent of breast development, or the way the person identified themselves, were all potentially open to examination. We would now consider many 'historical' hermaphrodites to be people with an intersex ${ }^{6}$ condition. Actual hermaphrodites, that is people with both sets of genitals and gonads, whilst still intersex people, are extremely rare.

To determine sex, firstly a decision had to be made as which of an individual's features were to be evaluated in order to make a decision as to what sex they were. According to Reis (4212), quoting from 'Aristotle's Masterpiece' (Aristotle [pseud.]), it is claimed that the Roman natural historian Pliny the Elder (c.23AD-79AD) took the view that there was no such thing as a hermaphrodite, only cases of mistaken sex when the size of the clitoris was misinterpreted. This is not an accurate representation of what Pliny wrote in his Natural History and modern translations provide several interpretations. On referring to the original text one sees that Pliny

5 See the later discussion on penis size in W v. W (Physical Inter-sex) [2001] High Court, Law Reports, Family Division. Case no. 111 and Bellinger v. Bellinger (Attorney-General Intervening) [2001] Court of Appeal (England \& Wales), Civil Division Case no. 1140.

6 Hermaphrodite now refers to an animal or human that is capable of being a mother to one child and a father to another, for example, the common garden snail can both impregnate and become pregnant. Intersex is an umbrella term for more than 40 different medical conditions that refer to complexity of the reproductive organs. The most common forms of intersex conditions are Complete or Partial Androgen Insensitivity Syndrome (CAIS or PAIS), Congenital Adrenal Hypoplasia (CAH), and Turner's Syndrome. (Rosario, 2008) 
actually said very little about the human, but refers instead to hermaphrodite fish (Pliny, Book 10, Chap. 87) and insects (Pliny, Book 11, Chap.109). Yet, the interpretation used by Reiss represents the idea that sex could be determined through sexual activity; the use the clitoris/penis is put to. Reis thus argues that the individual had the power to 'choose' their sex though their own choice of sexual activity-their psychological preference.

Similarly, according to Michel Rosin, Ulpian (c. 160AD-228AD), a Roman jurist whose writings have formed the core of the Corpus Juris Civilias, ${ }^{7}$ maintained that a 'eunuch' was to "belong . .. to the sex which prevails in him" (Rosin 98) but gives little guidance as to whether that refers to physical or psychological matters. Rosin interprets Ulpian to mean physical sex characteristics. In contrast, the medieval Islamic law of the 'Sunni Hanafi' school of Islamic Law considered the hermaphrodite to be a third sex rather than one or the other, but where sex had to be ascertained for inheritance or marriage purposes, the site of maximum stream of urination was evaluated, that is the dominant physical characteristics (see Bouhidiba).

Within modernist Roman and Common law contexts, legal sex was determined in quite different ways following one or either of these two systems; the psychological or the physical dominance in the body of sexual characteristics. Our analyses of reported cases show that the medieval and early modern courts found the diagnosis that a person was a medical hermaphrodite (that is had clear features of both sex organs), or was a person we would now know as having an intersex condition (a far more complex series of symptoms), irrelevant (see Turner and Whittle). The only legal concern was whether the bodily difference was significant enough to record one sex or the other. Most of the finer points of somatic variety that are used today to determine sex difference, such as chromosome structure or the form of gonadal tissue, could not, historically, be evaluated by the courts. Reliance had to be on distinctive physical features such as length of clitoris or depth of vaginal cavity, or alternatively on the emotional makeup and day to day gender presentation and gendered behavior of the person. There was no legal space or category in law for people who we would now know as hermaphrodites, or people with an intersex condition; people could not be both, they had to be either a man or a woman.

7 The Civil Law Code of the Roman Empire and the basis of many modern codified civil justice systems. 
Sex determination was not just important in terms of marriage and property matters, but also as to whether a person's sexual activity amounted to unlawful sodomy or tribadism, ${ }^{8}$ at a time when throughout most of Europe such activities were criminal offences punishable by hard labor or death (see Davenport-Hines; Traub).

\subsection{Roman Law and the Determination of Legal Sex}

Roman Law provided the model for the codified legal system of most of Modern Europe including the EU itself. The law is codified by the central state, and only legislative enactments are considered legally binding; judges interpret and clarify the code rather than make new law with their judgments. Consequently, in codified legal systems, the judiciary determine sex by reference to the requirements of the legislation, and by interpreting the personal and psychological preferences of the person in that context.

Well known within jurisprudence and gender studies is Michel Foucault's history of the French intersex person, Herculine Barbin. Designated female at birth, and raised as a girl, Barbin was examined after being discovered in a love affair with a woman and found to have a complex genital structure. The first question for the court was whether this was 'same' sex sexual activity. Consequently, the authorities insisted that Barbin choose to be one sex or the other. The choice s/he made was to be a man; the alternative choice, to be a woman, would have amounted to the admittance of lesbian tribadism, and potentially been punishable by death. 'Hercule' moved to Paris, but as a man, found s/he could not form a relationship. Barbin committed suicide rather than continue a life in which there was no coherent personal sense of self-knowledge and identity.

Foucault wrote of Barbin as an illustration of the hegemony of heteronormativity, but Barbin's story also illustrates what became an overriding principle of the modern Roman law jurisdiction on sex determination. It is up to the individual to choose a sex, but that choice must then be for life and it must be firmly placed within a heteronormative context. Any sexual activity they desired or had with a member of their chosen sex would be considered by law to be either sodomy or tribadism (or lesbian activity known by whatever similar local term) and

8 Tribadism is genital sexual activity between women. 
they would be expected to face the judicial consequences and punishment. Reis refers to the work of the late nineteenth century French medical jurisprudentialist Beck who mentions "an old French Law [that] allowed them great latitude. It enacted that hermaphrodites should choose one sex, and keep to it" (qtd. in Reis 438).

\subsection{The Common Law and the Determination of Legal Sex}

The general principle in Common Law systems is quite different. Common Law is far rarer in Europe. Used primarily by the United Kingdom and its former colonies or provinces, only the European countries of Ireland and Cyprus use a Common Law system outside of the UK. Though traditionally based on the principle of judicial precedent; that is the building of legal rules through the court decisions made by judges, in modern times Common Law states are increasingly codifying through law by the extensive actions of legislative parliaments.

The early English jurisprudentialist, Judge Henry of Bracton (c. 1210-1268) is recorded as clarifying that in the Common Law: "a hermaphrodite was [to be] classed with male or female according to the predominance of the sexual organs" (qtd. in Greenberg 277). In other words, by by the dominance of their somatic body features.

Three hundred years later in the sixteenth century, Lord Chief Justice and law reporter, Sir Edward Coke (1552-1634) said in his treatise on the laws of succession to hereditary wealth and title in England that

[e]very heire is either a male, or female, or an hermaphrodite, that is both male and female. And an hermaphrodite (which is also called Androgynus) shall be heire, either as male or female, according to that kind of the sexe which doth prevaile. (qtd. in Greenberg 278)

However, according to Traub, Coke was unusual in even acknowledging the existence of the possibility of a hermaphrodite, as by the early sixteenth century most writers were of the view that all people could be determined to be of one sex or the other.

What is clear, is that in Common Law the rules of precedent hold that a person's sex is to be determined through physical aspects of the body to be inspected. Thus, it became the job of the courts to make this determination. As opposed to decisions in the codified legal systems which were modelled after Roman Law, there is little mention of psychological sex (better 
termed as 'a personal sense of self'). And although Dreger (1998) reports many instances of when the law intervened to determine sex where a person had unusual psychological features that could be identified as belonging to both men and women, the gaze of Common Law was always on the physical.

For example, as late as 2000, in the English case of $W v W,{ }^{9}$ the question of whether a marriage required a divorce to end it, or was already void (that is, it had never existed), depended upon whether one of the spouses was a transsexual woman or an intersex woman. $W v W$ concerned a woman who had been a repeated victim of domestic violence at the hands of her husband. When she sought to divorce him, he counter claimed that she was transsexual, that is not a woman for the purposes of marriage - in which case the marriage would have been void (as if it never existed) and the 'husband' would have kept the vast majority of their joint property which he had deliberately placed in his name. The judge made the decision that $\mathrm{W}$ was an intersex woman based upon testimony she gave that her penis had been extremely small. The court refused to acknowledge the possibility of the transsexual person 'changing' their legal sex. ${ }^{10}$ Whether we believe W's testimony as to her penis size, there was no actual remaining evidence of the penis. Clearly the judge was looking for a way to get around finding that the marriage was void, as that decision would have been grossly unfair on a woman (transsexual or not) who had suffered tremendously whilst in the marriage.

However, this emphasis on physical aspects of the body in Common Law meant that in many cases sex determination was left to the judgment not of juridical but of medical experts. In fact, until the late twentieth century very few cases of sex determination came before the courts. Determination of legal sex in England was primarily in the hands of physicians. There are several early autobiographies of people who we would now view as being transsexual people, where it is clear that doctors cooperated in obtaining amended birth certificates and hence a new legal sex (see Allen; Cowell; Turtle). Nevertheless, what had been a historical lack of consensus between physicians, as mentioned by Dreger (1998), still existed and continues to exist to this day. One school of thought insists that being transsexual is a mental health

9 W v. W (Physical Inter-sex) [2001] High Court Family Division. case no. 111.

10 See the later discussion of the case of Corbett v. Corbett [1970] 2 All England Reports 33, 48; [1970] 2 Weekly Law Reports 1306-1324. 
problem (see Wyndsen). The other school of thought supports the hypothesis that a transsexual person is an intersex person, following research by Zhou and others, which showed a differential in few brain cells in the transsexual person. ${ }^{11}$ Furthermore, over the last twenty years, there have been increasing numbers of scientific articles being published outlining biological differences in the transsexual person's body and brain (see Rametti et al. 2011a and b; Hare et al.).

\subsection{The Gender Recognition Act 2004}

The Gender Recognition Act 2004 (GRA) is the UK's government's response to the decisions of the ECtHR in the cases of Goodwin v UK Government and I v the United Kingdom (both 2002). ${ }^{12}$ The cases highlight the way in which the institutional European courts have combined the principles of codified legal systems in allowing the person to 'choose' their own sex/gender, with the Common Law based precedent system of the ECtHR. It provides a fine example of the steering of Europe's moral compass by the Courts of Human Rights and, to some extent, the Court of Justice.

In the cases of Goodwin and I $v$ the United Kingdom the ECtHR held that accommodations should be made to recognize the new 'legal sex' of transsexual people, not by considering traditional or historical criteria but by holding that the matter-the change of sex-was a 'fait accompli' that the state enabled and should therefore recognize. Firstly, as the state allowed doctors to provide gender reassignment, therefore the state must consider a change of gender a reasonable thing for its medical services to provide. Secondly, as gender reassignment is not in any way easy, any idea that it is a matter of personal 'choice' or 'fancy' was no longer viable.

11 The primary problem with this debate is that Zhou et al's research does not enable determination of a person's physiological makeup until after death-as according to their research, the determining feature was found within a 'pin head' sized region of the brain of deceased trans women. Similarly it is impossible to determine that being transsexual is a mental health problem as it does not appear to have other mental health consequences for any other aspect of the transsexual person's functioning once gender transition has been facilitated (see Wilson, Sharp and Carr). The national press frequently presents articles discussing 'mistakes' where gender reassignment has not been the best treatment for a person, but there continues to be strong evidence that the quality of life and mental health is much improved for a significant majority of trans people since reassignment (see Pfäfflin and Junge, this research constitutes the most comprehensive longitudinal review of gender reassignment covering thirty years and reviewing over seventy studies of two thousand patients in 13 countries).

12 Christine Goodwin v. UK Government, [2002] European Court of Human Rights (application No. 28957/95) and I v. UK Government, [2002] European Court of Human Rights (Application No. 25608/94). 
And finally, with regard to affording rights, the debate on the etiology of transsexualism was of no great importance. Fundamentally, transsexual people exist, cause is irrelevant, what mattered is: "the unsatisfactory situation in which post-operative transsexuals live in an intermediate zone as not quite one gender or the other is no longer sustainable" (Goodwin and I v UK Government §70). Put simply, post-operative transsexual people could no longer be left with a 'no-sex', 'intermediate sex' or 'both sex' legal status. The court said:

a test of congruent biological factors can no longer be decisive in denying legal recognition to the change of gender of a post-operative transsexual. There are other important factors - the acceptance of the condition of gender identity disorder by the medical professions and health authorities within Contracting States, the provision of treatment including surgery to assimilate the individual as closely as possible to the gender in which they perceive that they properly belong and the assumption by the transsexual of the social role of the assigned gender. (§80, emphasis added)

The 'Corbett' test ${ }^{13}$ which previously was used for determining a person's sex in England and many Common Law states, including many US states, Ireland and Australia, was no longer acceptable and other factors had to be taken into account. The ECtHR effectively upheld the Civil Law principle that a line has to be determined, but the court went on and created a new set of determining factors:

Where a State has authorized the treatment and surgery alleviating the condition of a transsexual, financed or assisted in financing the operations and indeed permits the artificial insemination of a woman living with a female-to-male transsexual (as demonstrated in the case of X., Y. and Z. v. the United Kingdom ....) it appears illogical to refuse to recognise the legal implications of the result to which the treatment leads. (§78)

So, sex is to be determined through gender reassignment treatment. The judgment does not define what is meant by post-operative, basically ignoring this and preferring instead the concept of treatment as a generic term. The state would have to ban all gender reassignment

13 In the English case of Corbett v. Corbett [1970] 2 All England Reports 33, 48; [1970] 2 Weekly Law Reports 1306-24., Ormrod LJ devised a test for deciding a person's sex based on three factors: i. the chromosomal, ii. the gonadal and iii. the genital features at the time of birth of the individual concerned. Psychological sex was not to be included in any determination of legal sex. 
treatment, including assessment and hormone therapy, to avoid having to afford the recognition of the 'new' sex of a transsexual person.

Thus when determining 'legal sex', the Court's endorsement of the human rights basis for legal recognition of the new 'sex' of 'post-operative' transsexual people became a minimum line behind which the UK government could not retreat. The authorities had to provide legal registration which enabled trans people to enforce their rights to privacy, and their right to marriage to a member of the same natal sex under the European Convention. However, as a minimum line, it was perfectly possible for a government to go one step further and to make legal recognition available to those who are pre- or non-treatment and thus include those trans people who for health, disability or other reasons are unable or unwilling to undergo surgical intervention. This is exactly what the UK's Gender Recognition Act 2004 (GRA) has done.

The GRA affords legal recognition in the acquired gender (sex) role to transsexual people who have been diagnosed as having gender dysphoria, regardless of their surgical status (see GRA 2004, 3.2). The Act does not have specific medical requirements other than a diagnosis. Thus a person does not have to have undergone hormone therapy or gender reassignment surgery in order to obtain legal recognition (though it is acknowledged that these will undoubtedly ease the route to legal recognition). Consequently there may well be legal women who have a penis, and (more commonly because of the limitations of surgery to make a penis) men who have a vagina. Even though according to the ECtHR, the UK government could have decided to make gender reassignment surgery a pre-requisite for the right to marry, that route has not been taken. There were several reasons for making this decision: A few trans people who are living permanently in their new gender are unable to tolerate the doses of hormones because they will face serious health risks or even death, and some trans people are unable to have, or will not seek gender reassignment surgery.

His Honour, Harris J, the president of the first UK Gender Recognition Panel clearly was uncomfortable with simply receiving a diagnostic statement of gender dysphoria. Rather he wanted confirmation that gender reassignment surgery had been undergone, or at the very least was intended to be undergone. As such he read into Section 3 of the GRA a requirement that the medical reports should contain: "details of any treatment carried out or planned with 
a view to modifying sexual characteristics" (Harris §2). And specifically he required these diagnostic statements to include, under $\$ 12$ of the medical report for the Panel, to see: "details of the non-surgical (e.g. hormonal) treatment to date (giving details of medications prescribed, with dates) and an indication of treatment planned, and date of referral for surgery, or, if no referral, the reasons for nonreferral" (Harris §7).

In the same proposal, the Panel originally intended to see extensive diagnostic notes on each applicant stating that they had lived for at least two years in their new gender and committed to do so permanently in the future. These proposals were unacceptable both to the 'experts' meant to provide them, who argued that the time necessary to prepare the reports would become prohibitive in their National Health Service roles, and also to the trans community who vehemently argued that the law was being judicially extended beyond the original intention of parliament. Eventually an agreement was reached, but it was clear that the Gender Recognition Panel members were uncomfortable with the idea of legal gender recognition for non-operative transsexual people.

With the enactment of the GRA, a system of legal recognition is (almost) complete in the United Kingdom (we say almost, in that there is provision for religious bodies to not respect the privacy rights obtained in Goodwin and I). ${ }^{14}$ It includes the transsexual person's right to marry or contract a civil partnership in their acquired gender. Under the Act, transsexual people can apply for a Gender Recognition Certificate, which will make them legally a member of their acquired gender. If their birth was registered in the UK they will also be provided with a new birth certificate in that gender (GRA, S.21).

In the ten years, since the implementation of the Gender Recognition Act in April 2004, 3897 people (April 2014) have been awarded a gender recognition certificate (Ministry of Justice, 2014). Only seventy applications have been rejected, and most of these are ex-patriot trans people born in the UK, but who have undergone gender reassignment overseas. As such, they have initially been unable to meet the medical evidence requirements, as their medical reports were not produced by a physician registered with the UK's General Medical Council. New processes for approving overseas medical statements have been agreed upon, with the 
Gender Recognition Panel, and ex-patriot trans people have now been able to obtain their Gender Recognition certificates and new birth certificates.

\subsection{The New Sexes of the EU}

The European Court of Justice, of the 28 states of the EU, has also ignored the Corbett criteria in discrimination cases concerning transsexual people in recent years. ${ }^{15}$ Rather than concerning itself with the sex of the transsexual person, it has concerned itself with finding an appropriate comparator. In $P v S$ and Cornwall County Council ${ }^{16}$ the comparator was to be someone who had not undergone gender reassignment treatments. In $K B$, a complex case involving survivor pension benefits for the transsexual partner of a female NHS employee, the comparator was to be "a heterosexual couple where neither partner's identity is the result of gender reassignment surgery and the couple are therefore able to marry" (KB §31).

In the recent case of Richards $v$ Secretary of State for Work and Pensions, ${ }^{17}$ concerning discrimination in a transsexual woman's pension age entitlement, Advocate General Jacobs (AG Jacobs) appears to have gone much further than either the ECtHR or the GRA itself. The question was whether a trans woman who had not obtained a gender recognition certificate should have been entitled to full pension benefits as if always having been a woman. AG Jacobs' opinion is not binding but it was ultimately followed by the Court. AG Jacobs, in essence, proposed a new position which could significantly alter the determination of legal sex. Introducing a combination of the 'French' notion of personal choice and what had been, as early as 1970, the position of the English psychiatrist professor Armstrong, who was the expert ignored by Lord Justice Ormrod in the Corbett case, that a transsexual person has prebirth intersex condition, he suggests: "that the reasoning to be used in applying sex discrimination law to the case of transsexual persons should differ from the classical model

15 P v. S and Cornwall County Council [1996] European Court of Justice (Case C-13/94) Industrial Relations Law Reports 347; KB v (1) National Health Service Pensions Agency and (2) Secretary of State for Health, [2004] European Court of Justice, (case no. C-117/01) Industrial Relations Law Reports 240).

16 P v. S and Cornwall County Council [1996] European Court of Justice (Case C-13/94) Industrial Relations Law Reports 347.

17 Richards v. Secretary of State for Work and Pensions, [2006] European Court Of Justice, (case C-423/04), Opinion of Advocate General Jacobs, delivered on 15 December 2005. 
which is always based on a straightforward comparison between men and women" (Richards $\S 42)$.

As such, according AG Jacobs, in the case of $K B$, the correct comparator in the case of the female-to-male transsexual was therefore a male person whose identity was not the result of gender reassignment surgery. Therefore in Richards, "the correct comparator in the present case concerning a male-to-female transsexual person is a female person whose identity is not the result of gender reassignment surgery" (Richards §45).

Taken to its literal conclusion, if such a decision can be made with regard to pension rights which collect over a lifetime, then presumably that lifetime is to be regarded as if they have always been a person of the acquired gender throughout their lifetime. Could we then presume that regardless of what is said in the Gender Recognition Act 2004, that when transsexual people commence living in their acquired gender they then have the potential to ask the courts to determine that they have always been of that gender? As such, sex would become merely a matter of the enactment of choice.

The Gender Recognition Act 2004 has become the model for new forms of legal recognition of the transsexual person in Europe's states. In modern Europe, the sex/gender distinction has been retired. In the sex/gender distinction, female usually refers to sex (the sexed body), and woman usually refers to gender (the cultural meaning of living as a member of the female sex). In modern Europe, a person's gender (being a woman, or a man) defines their legal (as opposed to birth) sex.

This suggests an interchangeability of the terms. Normally in the sex/gender distinction sex precedes gender; gender is culture written onto the sexed body. But now gender precedes sex. One's preferred gender becomes the sex in which one is recognized in law. Europe has transformed gender identity to becoming legal sex-they are in effect, the same thing. Moreover, there is no recourse to the sexed body, which suggests that the body's sex as a taxonomical tool in Europe has become redundant.

\section{The Point of Europe}

The immense impact of the modern war that raged from deep inside Russia to the North African desert, from the air to the depths of the Atlantic Ocean, had led to huge losses of 
infrastructure and life in almost all European states. The need to ensure that the horrors of the Holocaust never happened again was seen by many as the paramount political issue of the time.

In 1945, the victorious nations of second great European war could either repeat the mistakes that followed the 1914-18 war; a league of nations to which they and others had merely given lip-service, further forging the nationalism which had resulted in the murder of millions of people who were considered 'less than human', or find an the alternative way of rebuilding as a group of nations working together for the good of all their citizens. The British Prime Minister Winston Churchill called for the creation of a "United States of Europe", saying:

I wish to speak to you today about the tragedy of Europe.

This noble continent, comprising on the whole the fairest and the most cultivated regions of the earth .... It is the fountain of Christian faith and Christian ethics. It is the origin of most of the culture, arts, philosophy and science both of ancient and modern times.

If Europe were once united in the sharing of its common inheritance, there would be no limit to the happiness, to the prosperity and glory which its three or four hundred million people would enjoy. Yet it is from Europe that have sprung that series of frightful nationalistic quarrels, originated by the Teutonic nations, which we have seen even in this twentieth century and in our own lifetime, wreck the peace and mar the prospects of all mankind. (Churchill, speaking in Zurich 19th September 1946)

Revisiting the activist, lobbying and legal campaigns for LGBT rights in Europe requires understanding of the response of Europe to Churchill's call; the division of post-war Europe into two separate jurisdictions. Firstly, the larger group of 47 states who are signatories to the European Convention on Human Rights (ECHR or European Convention), and secondly, the smaller group of 28 states who are members of the EU (the EU). How these two factions address rights through their legislative and jurisprudential roles has contributed considerably to developing the LGBT friendly policies, regulations, directives and case law of a Europe for the twenty-first century. 
Despite all the denials by the Euro-sceptic political right (see Cameron), the right's recent rhetoric has increasingly been one of isolationism, consequential to the damage sustained as a result of the Western world's recent financial crisis (see Kolyako). Academic lan Manners would argue that Euro-sceptics, like David Cameron, the UK's Prime Minister, have missed the point about Europe. In 2002, Manners argued that the EU has a key role as a 'normative power' (see Manners 2002) and simply its existence has meant the EU has changed the norms that exist within world politics, away from the practice of nationalistic and isolationist interests, directly challenging the 'expectations of state-centricity' that has previously existed in world politics (see Manners 2008). We can extend Manners' theories to include not only the EU, but also the larger group of $\mathbf{4 7}$ states that are signatories to the Convention and which make up the Council of Europe $(\mathrm{COE})^{18}$-in particular, the case law of the ECtHR. It is in the light of Manners' suggestions that it is possible to consider the development and current position of these two European jurisdictions, the CoE members, and the EU members, and how they currently respond to questions of minority rights.

\subsection{The Council of Europe and the European Convention on Human Rights}

The [Hague] Congress ...

(9) CONSIDERS that the resultant Union or Federation should be open to all European nations democratically governed and which undertake to respect a Charter of Human Rights.

(10) RESOLVES that a Commission should be set up to undertake immediately the double task of drafting such a Charter and of laying down standards to which a State must conform if it is to deserve the name of a democracy.

(11) DECLARES that in no circumstances shall a State be entitled to be called a democracy unless it does, in fact as well as in law, guarantee to its citizens liberty of thought, assembly and expression, as well as the right to form a political opposition. 
(13) IS CONVINCED that in the interests of human values and human liberty, the Assembly should make proposals for the establishment of a Court of Justice with adequate sanctions for the implementation of this Charter, and to this end any citizen of the associated countries shall have redress before the court. (The Hague Congress)

The Convention itself was drafted in response to a call from the 1948 Hague Congress for a 'charter of human rights' and a court which ordinary people can use to enforce it, unlike the United Nations Declaration of Human Rights (see Couvreur). British politician and judge, David Patrick Maxwell Fyfe, was rapporteur to the drafting committee, a role often criticized for resulting in a convention that is considered by some to be culturally biased towards a purely Western idea of rights (see Sweeney; lovane).

Since 1950, 47 European states have now acceded to the CoE and ratified the Convention on Human Rights. Iceland is also a signatory and there are numerous small former colonial, overseas protectorates, such as Guyana on the North Atlantic coast of South America, several Caribbean islands and the British Overseas Territory, the Falkland Islands (Isla Malvinas), which are also subject to aspects of the Convention. Belarus and Kazakhstan are currently seeking inclusion but have been refused entry to date, because of concerns about a lack of democracy and human rights abuses in those states, particularly towards LGBT and other minority groups.

The Convention is managed by an executive body, the CoE based in Strasbourg. The oversight and policy body is the Council of Ministers, made up of government Ministers from all of the member states. The Council of Ministers appoints the judges to the European Court of Human Rights who hear cases where a signatory state has been accused of contravening an individual's human rights or fundamental freedoms as defined by the Articles of the Convention. ${ }^{19}$

The ECtHR is both stemmed in the codified convention of Human Rights and through its own precedent based decisions. It moves carefully, giving considerable weight to what is called the 'Margin of Appreciation'. The Margin is a calculated overview of the difference in social and

19 The Vatican City and the Roman Catholic Church, which it represents, is extremely influential, despite being unable, as theocracy, to abide by the democratic rights contained in the International Covenant on Civil and Political Rights (see United Nations General Assembly 1976), and therefore being excluded from accession. Personal experience has seen that despite only having observer status within the Council, in reality, when it chooses, the Vatican can obtain a seat at many of the working committees of the Council of Europe. 
policy attitudes within signatory states. Following Manners' discussion of the EU as a normative body (see above), it can be argued that the same principles can be applied to much of the work of the CoE and the ECtHR, over the last twenty years. Decision making by the ECtHR shows strong evidence of a steady and increasing pace towards developing public policy in which LGBT people and others have their rights recognized by the court and the executive; the CoE has responded to this in a way to creating change for the better.

\subsection{The EU and its Treaties}

The [Hague] Congress ...

(3) DECLARES that the time has come when the European nations must transfer and merge some portion of their sovereign rights so as to secure common political and economic action for the integration and proper development of their common resources.

(4) CONSIDERS that any Union or Federation of Europe should be designed to protect the security of its constituent peoples, should be free from outside control, and should not be directed against any other nation. (The Hague Congress)

It had been the wartime loss of infrastructure that led to calls for the creation of a new authority to collectively handle key economic resources. Not only would this make Europe's states more interdependent and therefore make war less likely, but it would provide economic and structural advantages in the event of any part of Europe being attacked by any rogue or outside state.

The European Union, initially founded between $1951-58$ by just six states, has gradually grown to the current 28 states, with the accession of Croatia on 1 July 2013. It has several key institutions, but importantly for LGBT rights, the European Parliament, in Brussels and Strasbourg, is the EU's legislature, which agrees the Union's regulations and directives, and the European Court of Justice, based in Luxembourg, provides the judicial interpretation whenever the meaning of regulations or directives is questioned. 
lan Manners asks whether by being a normative power, the EU also acts in an "ethically good way" and what are the "ways in which we might judge the normative ethics of the EU in world politics" (Manners 2008, 65). It seems clear, in recent years, that the consideration given to changes to law and policy for the benefit of LGBT people that has developed within the EU institutions, particularly within its executive, the Commission, its Parliament, and the Court of Justice, has shown the extent to which they are prepared to act both normatively and ethically. The ongoing role these institutions have adopted of challenging arbitrary discrimination, promoting citizen equality, demanding the recognition of rights, and listening to the less powerful, has been so significant, that they have impacted massively on the potential for LGBT and other minority rights on the world stage.

There is a considerable body of evidence to demonstrate that EU institutions are being both normative and ethically good, and it seems that protecting the rights of minorities including LGBT people has become one of the key social roles and purposes of the EU institutions. It is a program that is making considerable waves and creating change elsewhere.

\subsection{Theories of Europe and Change}

Born from the demand to ensure there would never be a repeat of the catastrophic genocide of the Holocaust, modern Europe has a voice that takes its time to ensure it always speaks with respect, and is always reasonable and responsible.

We can, however, still see a significant difference between the responsible modernist project as expressed by the larger institution of Europe, and the apparent failures of that same project in the Europe of its parts; the nation states. Effectively it is the difference between the theory and the practice of Europe. There is the theoretical framework of a Europe born out of the worst of man's inhumanity to man, and at the personal level the individual's relationship with formal religion, Catholic or Protestant, and its moral values. The national, as opposed to European, practice of these values demonstrates a desire to reproduce the practices of a group of former colonial and imperialist nationalist powers, in which personal superiority as a 'Christian', 'white', European was God given (see Moor and Simpson).

For most European citizens, this history is simply a backdrop to life. But it comes sharply into focus when discussing those who are the 'other' of the meaning of European citizenship. Anyone who does not live the life of the healthy, wealthy, fit, white, middle class, 
heteronormative European is still often presented by the media and press as not having a place within European life. However, as Kate Nash has shown, this has improved considerably for LGBT people in recent years (see Nash). LGBT people, whether presenting difference in their sexual partner choice or their gender identity presentation, daily face the difference between the theory and practice of Europe. At times, it seems that Europe, its politics, its culture, its people and even the land they live on cannot escape the dialectic of its own modernist dualisms where the queer other simply joins a long line of 'others' who always just miss out on the best benefits of the modern European project, or as Mojs puts it:

For the Union to be an effective and legitimate normative power it must exercise consistency between its internal and external policies. If the Union wants to speak authoritatively on LGBT-related human rights issues, it must thus not only reach a certain 'value consensus of acquis éthique' . . . but this de jure situation must also be reflected in the lived experiences of LGBT people in the EU itself. (83)

\section{The Development of a Queer European Sensibility}

Gradually from small roots in the mid-twentieth century, such as the founding of COC Nederland in 1946, the UK's Homosexual Law Reform Movement in 1957, ${ }^{20}$ the Minorites Research Group, ${ }^{21}$ and Arcadie in France (see Jackson), by the 1990s a powerful LGBT movement had emerged in Europe. Initially the struggles were concerned with the removal of criminal sanctions from same-sex sexual behavior, and to a large extent throughout Western Europe they have accomplished the repeal or modification of sodomy, buggery and other homosexually identified criminal laws, though often achieved despite great reluctance from state legislators (see Waaldijk). One can point to an increasing and general public consensus that what individuals did in the privacy of their own homes was either their own business or, at the very least, not the appropriate subject of criminal sanction.

20 The Homosexual Law Reform Society became the Campaign for Homosexual Equality, after the implementation of the decriminalization of the age of consent for gay men in the UK, in the Sexual Offences Act 1967.

21 The Minorities Research Group was a late 1960s lesbian support organization in the UK. 
In 1994, referring to the change in non-discrimination laws for lesbians and gay men in Europe, Kees Waaldjik claimed:

There seems to be a general trend of progress; where there is legal change it is change for the better. Countries are not all moving at the same time and certainly not at the same speed, but they are moving in the same direction-forward. (Waaldijk 51)

Waaldijk's later work has shown there have been further significant changes since 1994 (see Waaldijk et al.), but there is no doubt that the map of Europe is still massively divided on many aspects of rights for LGBT people (see ILGA-Europe 2012).

The largest stumbling block to a truly Queer Europe has been lack of progress at national institutional and structural levels, primarily because of the pseudo-Christian interests of some states. In particular the Christian evangelical movement's increasing involvement in national politics has deterred some states from grasping the issue and making real change. It is the nation states and not Europe, where the real problem lies when it comes to LGBT rights.

Aside from lobbying for legal reform, from the mid-1980s, the more active LGB and T organizations took the route of supporting cases going to the European Courts, most notably the UK LGB pressure group, Stonewall, which supported 'Age of Consent', 'Employment', 22 and 'Privacy when Gay in the Military' cases. ${ }^{23}$ Similarly, the 1990s saw the growth of a new 'trans' movement seeking rights for transgender people including non-discrimination and equality rights, and access to medical gender reassignment for those who want it, and in particular a large focus on the right to personal safety. Press for Change in the UK is perhaps the most successful of the national transgender groups. ${ }^{24}$ The success of its campaigns, using political lobbying, social education and legal case work won:

22 Grant v. South-West Trains [1998] European Court of Justice, (case C-249/96) European Court Reports I-621.

23 Age of Consent cases: see Sutherland v. UK [1998] European Court of Human Rights, European Human Rights Law Review 117, Employment rights and Employment in the Military for Gay men and lesbian women: see Smith and Grady v. UK [1999] European Court of Human Rights, European Human Rights Reports 29: 493, and Lustig-Prean and Beckett v. United Kingdom [2000] European Court of Human Rights, 29 European Human Rights Reports 548.

24 The internet platform of Press for Change (PFC) can be found at http://www.pfc.org.uk. 
- workplace protection throughout the European Union in $1995,{ }^{25}$

- recognition of LGBT families as de facto families within Europe, ${ }^{26}$

- national health care rights in $1999,{ }^{27}$

- the right to legal recognition of the preferred gender role throughout the 47 signatories to the European Convention in 2003. ${ }^{28}$

Press for Change also pushed through cases in both the European Court of Justice (ECJ) ${ }^{29}$ and the ECtHR, ${ }^{30}$ successfully arguing that pension benefits were workplace benefits and accordingly should be given at age sixty to trans women. Press for Change provided a model of how to create legal and social change which has since been adopted by many other national and international transgender Groups. In particular, Press for Change broke free of the medicolegal-heteronormative control of trans people through their work on ensuring that legal recognition legislation ${ }^{31}$ was provided without pre-existing medical or surgical requirements, including sterilization (see Whittle et al. 2000).

The wider transgender Community in Europe followed with cases building upon this work, including claims that successfully challenged:

- compulsory requirements before legal gender recognition as contravening Art.8, the Right to Private and Family Life, e.g. in the case of $L v$ Lithuania, genital reconstruction surgery was a requirement for gender recognition, but a legislative gap meant it could not be obtained by Lithuanians, ${ }^{32}$

25 P v. S and Cornwall County Council, [1996] European Court of Justice (case no. C-13/94), Industrial Relations Law Reports 347.

$26 X, Y \& Z$ v. United Kingdom [997] European Court of Human Rights, 24 European Human Rights Reports 143.

27 A, D \& G v. North West Lancashire Area Health Authority [1999] Court of Appeal (England and Wales), Lloyd's Law Reports Medical 399.

28 Christine Goodwin v. UK Government, [2002] European Court of Human Rights (application No. 28957/95) and I v. UK Government, [2002] European Court of Human Rights (Application No. 25608/94).

29 Richards v. Secretary of State for Work and Pensions [2006] European Court of Human Rights (case.no.C423/04) All England Reports (EC) 895.

30 Grant v. United Kingdom [2006] European Court of Human Rights (Appl. No. no. 32570/03).

31 The Gender Recognition Act 2004.

32 L. v. Lithuania [2007] European Court of Human Rights (Appl.no.27527/03). 
- compulsory requirements before the reimbursement of health costs as contravening Art.8, the Right to Private and Family Life and Art.6, the Right to a Fair Trial for example in the case Schlumpf v Switzerland, a rigid two years of 'Real Life Experience' was a requirement for an elderly trans person before reimbursement of gender reassignment medical costs would be considered, although there was no such requirement in the International care standards (see Coleman et al. 2012). ${ }^{33}$

The wider European LGBT rights movement has not satisfied itself with simply achieving case law success and consequent legal change, but has gone further to seek out a wide range of other rights and benefits. It has gone on to win major victories in the European Courts, including claims that:

- physical abuse, humiliation, and causing severe mental distress while in police custody contravened Art.3, the Right to be Free from Torture, ${ }^{34}$

- the authorities' repeated banning of a gay group from meeting in Pirin contravened Art.11 of Right to Freedom of Assembly, ${ }^{35}$

- the refusal of a 'gay rights' parade in Moscow, contravened Arts 11, the Right to Freedom of Assembly and Association, and Art. 13, the Right to an Effective Remedy and Art.14, the Right to Non-Discrimination, ${ }^{36}$

- using the sexual orientation of a person to determine which parent should have custody of a child contravened Art.8, the Right to Private and Family Life and Art.14, the Right to Non-Discrimination, ${ }^{37}$

33 Schlumpf v. Switzerland, [2009] European Court of Human Rights (Appl. no. 29002/06).

34 Ribitsch v. Austria [1995] European Court of Human Rights (Appl.no. 18896/91) European Human Rights Reports 55.

35 United Macedonian Organisation Ilinden and Ivanov v. Bulgaria [2005] European Court of Human Rights (Appl.no. 46336/99).

36 Alekseyev v. Russia [2010] European Court of Human Rights (App.no 4916/07, 25924/08 and 14599/09).

37 Mouta v. Portugal, [1999] European Court of Human Rights (Appl. no. 33290/96). 1999-IX European Court of Human Rights Series A: Judgments \& Decisions. 309. 
- exclusion of individuals from the application process for adoption of children simply because of their sexual orientation contravened Arts 8, the Right to Private and Family Life, and Art.14, the Right to Non-Discrimination. ${ }^{38}$

The transgender movement in Europe has gone on to seek the extension of legal equality in a range of social spheres including demands for inclusion in anti-discrimination legislation, spousal and family rights, adoption, an equal right of access to healthcare and other forms of social entitlement that would be afforded to heterosexual, gender normative people in Europe (see Whittle et al. 2000). In many ways, the transgender movement has pushed both the EU and the wider states of the CoE Europe in a way which has forced European institutions to engage as Manner's normative and ethical Europe.

The national organizations have co-operated extensively, taking part in a series of European councils of trans activists, which led to the formation of a representative organization: Transgender Europe. ${ }^{39}$ And by co-operating with ILGA-Europe, Transgender Europe has maintained a unique voice yet at the same time, gained the power of a much larger movement. The community has extensively addressed gender stereotyping, personally and organizationally, and within clinical gender reassignment services. That has led to significant movement as regards transgender health care, especially with the publication of the World Professional Association for Transgender Health's (WPATH) International Standards of Care Version 7 (Coleman et al. 2012). More Pressure has come from the European Parliament who in 2011 called for the World Health Organization to remove gender identity disorders from the International Diagnostic Manual ICD 11 (see European Parliament). The French Government has also effectively de(psycho)pathologized gender identities by removing the diagnosis from the French version of the $I C D 10$ (see Hinkle).

The transgender activist movement has very effectively engaged with the European institutions, leading to significant reports and publications promoting trans rights coming out of the Fundamental Rights Agency of the EU, the European Commission and the office of the CoE's Commissioner for Human Rights, which has also funded research into health care for

38 E.B. v France [2008] European Court of Human Rights (Appl. no. 43546/02).

39 The internet platform of Transgender Europe (TGEU) can be found at http://www.tgeu.org. 
trans people and ensured full inclusion in new LGBT social and legal research. The commissioner himself has written an issue paper on the problems faced by trans people in the Convention countries (see Hammarberg 2009b). Trans activists also worked with LGB activists to obtain signatures from 44 European states for the 2008 UN "Statement on Human Rights, Sexual Orientation and Gender Identity" (United Nations General Assembly 2008).

Although the European transgender movement is technically lagging behind the LGB rights movement, it has caught up rapidly, enabling these institutions to recognize what Hammarberg identifies as "the transgender rights deficit" (see Hammarberg 2009b).

\subsection{The Dark Side of a Queer Europe}

We are also disturbed that violence, harassment, discrimination, exclusion, stigmatisation and prejudice are directed against persons in all countries in the world because of sexual orientation or gender identity, and that these practices undermine the integrity and dignity of those subjected to these abuses. (United Nations General Assembly 2008, Art.5)

From the very first stirrings of gay rights activism, the moves to gain equality have been resisted. Resistance has often been at the structural and institutional level, but most importantly it is felt by the individual (see Turner and Whittle).

Homophobia is a misnomer and might be better referred to as 'queer bashing'; the physical violence that is used against people solely because they are gay, lesbian, or trans is primarily based upon perceptions of a person's apparent non-normative gender identity or expression. Sexual orientation is implied, and may well be unknown (see Turner and Whittle). Particularly in 'stranger' violence, a person gets beaten up because of who the attacker thinks they sleep with. That decision will be based upon a person's gender presentation; the way they move, or the sound of their voice, rather than their actual sexual practices. Homophobia and transphobia are still significant problems within the European Union (see Whittle et al. 2008). In the 47 states that make up the larger Europe, it is so prevalent that it causes many LGBT people to fail to fulfil their potential. In recent research, one of the more shocking features has been the extensive reporting of the extent to which LGBT people make suicide attempts (see Whittle, Turner and Al-Alami). Because of the limits in reporting on an individual's death, it is currently impossible to count the true level of successful suicides. 
Private citizens continue to perpetrate anti-LGBT violence, and national institutions in many countries, including those in the west of Europe, have continued to look away whilst lesbians, gay men and trans people have faced harassment and have been brutalized by their relatives (see Browne), their co-workers (see Whittle, Turner and Al-Alami) their schoolmates (see Turner and Whittle), and the national press (see Watson and Whittle; Lees). The stigma attached to being gay or trans has often stopped them from reporting their victimization, and public officials have typically remained indifferent to the problems, even after the CoE's Recommendation of the Committee of Ministers on Combating Discrimination on the Grounds of Sexual Orientation or Gender Identity was implemented in 2010 (see ILGA-Europe 2013).

Over the last 15 years in particular, there has been a growing awareness of the personal violence perpetrated against lesbian, gay, bisexual, and transgender (LGBT) individuals, not just within the queer community, but also amongst heterosexual allies. The 1999 bombing of the Admiral Duncan pub, a gay bar in London's Soho district, highlighted and raised this awareness. The bomb, set off by the neo-Nazi militant David Copeland, the 'London Nail Bomber', left three people dead; Andrea Dykes, who was four months pregnant with her first child, and her friends Nick Moore and John Light. They had been celebrating Andrea's pregnancy along with her husband, Julian, who was also seriously injured in the attack. 79 other people were also injured, many of them seriously, and four of the survivors had to have limbs amputated (see Hopkins).

The death of Andrea Dykes and her husband, and the role of Copeland in two other racist bomb attacks significantly raised the awareness of homophobic violence amongst heterosexual as well as LGBT people. The key to changing attitudes, as research has shown in many fields, including race and disability, is that

having contact with minorities is the factor with the most positive influence on people's attitudes. When rating out of 10 how comfortable (with 10 being completely comfortable) they would feel with an LGBT person attaining the highest elected office in the land, those with LGBT friends gave an average rating of 8.5, while those without gave an average rating of 5.5. (Council of Europe 27)

Seeing LGBT people in ordinary life is essential to lowering prevalence of homophobia. Notably, the lesbian, gay and trans movements have perhaps had their greatest impact at the level of 
everyday life and culture. Television, film, media, education and religious institutions all became sites of struggle and in many cases slowly but surely have become the agents of normalization. These have effectively supported the gains in getting heterosexual people to recognize the issues and problems faced by LGBT people, and more than anything within some nation states, such as the Netherlands, Italy, the UK and France, have made LGBT life very much part of national public life.

As we move forward in the twenty-first century, Europe is beginning to see the stirrings of a citizen's movement on the left in loose activist groups such as Occupy (see Gray), environmental and animal welfare campaigns. This movement is inclusive of a wide range of critical issues, including informal, but international queer movements promoting one off issues, for example The International Day against Homophobia, ${ }^{40}$ the Stop Transgender Psychopathologisation 2012 campaign, ${ }^{41}$ the International Transgender Day of Remembrance, ${ }^{42}$ and Equal Love, a same sex marriage campaign. ${ }^{43}$ This has translated to many local level actions within Europe such as the one off campaign in France which effectively removed transgender people from the psychiatric diagnostic framework (see Faure); the recent call for the sacking of a British Journalist after the transsexual teacher Lucy Meadows committed suicide after being 'outed' (see Lees), the campaign to have required sterilization removed from new Swedish legislation for Gender Recognition (see Ederyd), and the campaign to have anti-gay advertisements pulled from London buses (see Booth, Mulholland and Strudwick). At the supranational level there are now very influential organizations such as Transgender Europe and ILGA-Europe. Originally voluntary organizations, their professional executive teams work closely together, yet they maintain contact with the activist base they rely on for the institution of a Queer Europe.

When we discuss Europe, we are torn between what it was and what it is, what it is and what it should be. Equality of life opportunities and lifestyle as well as equality before the law is a moderately recent jurisprudential concept. The initial demands to change the law in relation

40 See their internet presence at http://www.dayagainsthomophobia.org.

41 See http://www.stp2012.info/old/en.

42 See http://www.transgenderdor.org/.

43 See http://equallove.org.uk/. 
to any group of people who were disadvantaged by prejudice and discrimination were framed around the notion of preventing that discrimination. Just as the laws abolishing slavery never set out to make former slaves equal to those who had been their masters, until the early part of the twenty-first century the process of gaining access to civil and political rights was always problematic. Regulations intended to afford equality were doomed to failure because they were essentially based on principles of behavioral control, that is preventing discrimination, and not in liberationist politics; the creation of some sort of equality.

Peaceful campaigning against discrimination has formed the backdrop to all 'characteristic' based protection in law in Europe. Inherited from the American civil rights movement, the purposive nature of campaigning was to demand legislation that would put an end to the negative treatment of LGBT people.

The pathway taken to create change in Europe has roots both in left wing activism and identity politics. However, reflecting on the actual mechanisms of the change on the road towards equality, it seems it has largely been a consequence of judicial decisions driving the agenda. Yet, as I have argued elsewhere, it would be incorrect to claim that the history of recognizing the rights of lesbian, gay, bisexual and transgender people both, before the law and in society, has come about as a consequence of political or jurisprudential ideology (see Whittle 2007). Initially legislators and Judges had to be pushed and pulled towards change.

The ongoing political struggles for transgender and/or same sex marriage in states like Austria, Germany, the UK and Ireland, were, for a long time, fought within the framework of European modernist dualisms. Most notably, the struggles took place in a space between truth and a pretense of religiosity, which hampered progress. These struggles brought the limits of states with pseudo-Christian governments sharply into focus. As Martin Mojs said:

the [European] Union's ability to project its sexual ethics into the international realm is severely hamstrung by a series of inconsistencies. Internally, even though European level provisions should have created a situation of de jure equivalence with regards to the principles of equal treatment and non-discrimination, reports on the pervasiveness of institutionalised and societal homo- and transphobia showed how there is no de facto level-playing [sic] field. (83) 
The lack of a level playing field has meant the protests movements we now see could not have come without activism and social politics raising the consciousness of a few brave and determined people who, in the early days were prepared to put themselves on the line and challenge what they saw as unjust laws through the apparatus of the European Courts, so enabling the judiciary as well as other European institutions to do the ethically correct thing.

Once they started, though, they have rapidly moved forward to an understanding of equality, rights and even liberation for LGBT people. Consequently, now, the judicial work in Europe is extremely influential. For example, it provided safe ground for discussion in the development of the International Yogyakarta Principles, which lay out the Human Rights of LGBT people and which have now become a key reference throughout the world (see Alston et al.). The individuals, who challenged and continue to challenge their nation states through the mechanisms of the European Courts, have meant that key wins have allowed activism in Europe to flourish. Before those many individual cases, the only safe place in Europe was still in the closet.

\subsection{A Normative and Ethical Queer Europe: The Treaty of Lisbon}

Prior to the Treaty of Lisbon coming into force on 1 December 2009, citizens of the EU understood their 'European' rights within the context of the 'common market'. Market rights fell under the control of the European Parliament and Commission in Brussels, and the European Court of Justice and LGBT rights could only exist if they could be molded to fit into the context of market based economic rights. A typical example would be transgender rights to non-discrimination in employment. As was seen in the case of $P v S$ and Cornwall County Council $^{44}$ at the European Court of Justice, it required the codified wording of the directive or regulation so the courts would be able to interpret it. In that case the relevant directive referred to gender and not sex so the court felt able to say that it included protection from discrimination due to a change of gender, as well as a difference between genders. However,

44 P v. S and Cornwall County Council [1996] European Court of Justice (case C-13/94) Industrial Relations Law Reports 347. 
in the same sex partner case of Grant v. South West trains, ${ }^{45}$ there was no flexibility in the text and so the court felt unable to help.

Similarly, prior to the Treaty of Lisbon, civic and social rights - what we call human rightswere seen as the remit of the ECtHR in Strasbourg. The Treaty of Lisbon confirmed the EU's accession to the European Convention on Human Rights (see European Commission). At the same time, the Treaty also brought into force the European Charter of Fundamental Rights of the EU. The Charter encompasses the rights of citizens of the EU. It did not create new rights as such, but it gathered up into one source, what were already existing rights albeit scattered over a range of international sources. And the Treaty requires national courts as well as the Court of Justice to consider the Charter. The Charter is very similar to the Convention but has less derogations and therefore is potentially more useful. Effectively the Lisbon Treaty has embedded the Charter in the Convention of Human Rights, and vice-versa. The two jurisdictions, the sets of institutions, and the courts have become so closely related, one could argue there is no longer any need for two separate Europes. Jackie Jones (Bristol Law School) has said: "The EU is not just an economic union it is equally a social union, based on a social contract between it and its people" (Jones 300).

Referring to the key elements of human dignity, integrity of the person, equality, security, prevention of torture, privacy, development of personality, fair employment, decent housing, all of which are contained within the Charter, (Jones 300); Jones believes that combined with the convention and the jurisprudence of the ECtHR, in particular the Court's judgments on personal privacy and the right to personal autonomy, there is no doubt that the European Court of Justice could now use its jurisprudence to force recalcitrant nation states, such as those in the former Soviet bloc countries, to respect the rights of their LGBT citizens in a substantive way, effectively mirroring the Convention rights, into the social contract within the EU.

Many former Eastern bloc countries have positively engaged with the new LGBT rights of Europe, for example Serbia and the Czech Republic. Others have done their best to protect the rights of their national courts to sidestep the 'dignity' obligation for sexual orientation. 
Hungary, which had taken many proactive steps towards LGBT rights, now has a right wing nationalist government, which has taken a retrograde step of banning same sex marriage within the national constitution. Similarly, Poland, which, historically, has never criminalized sexual orientation, has insisted on the inclusion of Declaration 61 in the Treaty, which states that:

The Charter does not affect in any way the right of Member States to legislate in the sphere of public morality, family law, as well as the protection of human dignity and respect for human physical and moral integrity. (European Commission 326)

In Declaration 53 of the Treaty, the Czech Republic inserted a declaration referring to the core principle of subsidiarity in the EU, ${ }^{46}$ going on the emphasis

that the Charter does not extend the field of application of Union law and ... does not diminish the field of application of national law and does not restrain any current powers of the national authorities .... (European Commission 357)

There are many of these claims to exception, but the reality is that the tide is turning. Europe is becoming increasingly queer, and the pink is spreading-partly through the economic power of the pink pound, but also due to increasing television and film representations that have made LGBT people no longer just characters to be mocked and pilloried in the Big Brother House, but also artists, presenters, news readers, writers, film makers, actors and the rest who are choosing to be 'out', effectively enjoying the safety of numbers now afforded by Europe's mass activism. Ultimately though, they could not do that without the endless stream of reports, recommendations, and other reading matter (much of what has been cited in this paper) pouring out of what are now pro-LGBT rights civil servants within the European institutions, and pro-LGBT judges within the courts.

Sadly, Europe remains mute on the question of intersex rights, notably the questions of surgical alteration of baby's genitalia, and the right to gender recognition. These questions have been raised at national levels, primarily by trans activists who acknowledge the many

46 Declaration 18 of the Treaty confirms the principle of subsidiarity and division of competences between the European Union and its Member States, meaning that wherever possible decisions within the EU are left at the lowest possible administrative or judicial level, for example national courts and tribunals. 
intersex trans people in their midst. Consequently, there has been some acknowledgement in medicine of the need to consider whether genital surgery after birth is the right way forward. However, the failure to raise these issues in Europe's courts has left the practices of intersex gender recognition, and intersex genital surgery unregulated. The lack of actual intersex activist organisations has, so far, left intersex people without a voice or a place in the legal framework of Europe. However, activism has certainly been the key to change within Europe. The mass LGBT activist movements of the modern 'Europes', have been incredibly successful in ensuring it is becoming OK to be LGB or T in much of Europe, and the movement will continue to spread simply because it is becoming ordinary and normal for people to have LGB or T people as their neighbours, in their families, as work colleagues, as lovers, and crucially; as their politicians, their civil servants and their European technocrats. Sexual orientation and Gender Identity Rights really are a shining example of the power of lan Manner's Normative and Ethical Europe.

\section{Works Cited}

Allen, Robert. But for the Grace. London: Allen, 1954.

Alston, Philip, et al. The Yogyakarta Principles. The International Panel of Experts in International Human Rights Law and on Sexual Orientation and Gender Identity, March 2007. Web. 1 March 2013. <http://www.yogyakartaprinciples.org/>.

Aristole [pseud.]. The Works of Aristotle the Famous Philosopher in Four Parts. New England: N.p., 1806.

Booth, Robert, Hélène Mulholland, and Patrick Strudwick. "Anti-Gay Adverts Pulled from Bus Campaign by Boris Johnson." Guardian. Guardian, 12 April 2012. Web. 15 Nov. 2012. <http://www.guardian.co.uk/world/2012/apr/12/anti-gay-adverts-boris-johnson>.

Bouhdiba, Abdelwahab. Sexuality in Islam. Trans. Alan Sheridan. London: Routledge, 1974. Browne, Katherine. Domestic Violence and Abuse: Count Me in Too. Brighton: $U$ of Brighton, 2007.

Cameron, David. "EU Speech at Bloomberg." Number10 Downing Street: The Official Site of the Prime Minister's Office. Cabinet Office and Prime Minister's Office 10 Downing Street, 23 
January 2013. Web. 30 Jan. 2013 <http://www.number10.gov.uk/news/eu-speech-atbloomberg/>.

Churchill, Winston. "Something to Astonish You: Mr Winston Churchill speaking in Zurich 19th September 1946." The Churchill Society London. The Churchill Society London, n.d. Web. 1 Oct. 2013. <http://www.churchill-society-london.org.uk/astonish.html>.

Coleman, Eli Bockting et al. "Standards of Care for the Health of Transsexual, Transgender, and Gender-Nonconforming People, Version 7." International Journal of Transgenderism 13.4 (2012): 165-232.

Council of Europe. Discrimination on Grounds of Sexual Orientation and Gender Identity in Europe. Strasbourg: Council of Europe Publishing, 2011.

Council of Europe. Convention for the Protection of Human Rights and Fundamental Freedoms. Strasbourg: Council of Europe, 1950.

Couvreur, Philippe. "Upholding the Rule of Law at the International Level: The Role of the International Court of Justice." UN Chronicle 49.4 (2012): n. pag. Web. 3 Sept. 2013 <http://unchronicle.un.org/article/upholding-rule-law-international-level-role-internationalcourt-justice/>.

Cowell, Roberta. Roberta Cowell's Story by Herself. London: Heinemann, 1954.

Davenport-Hines, Richard. Sex, Death and Punishment. London: Collins, 1990.

Downing, Lisa, and Robert Gillett. Introduction. Queer in Europe: Contemporary Case Studies. Eds Lisa Downing and Robert Gillett. Farnham: Ashgate, 2011. 1-10.

Dreger, Alice D. Hermaphrodites and the Medical Invention of Sex. Cambridge, MA: Harvard UP, 1998.

Ederyd, Caisa. "The Swedish Government Has Stopped Sterilising Transgender People." Vice. Vice, 14 Jan 2013. Web. 3 Nov. 2013. <http://www.vice.com/en_uk/read/forced-sterilisationtransgender-community-sweden>.

Equal = Love. Web. 20. May 2013. <http://equallove.org.uk/>.

European Commission. "Consolidated versions of the Treaty on European Union and the Treaty on the Functioning of the European Union - Charter of Fundamental Rights of the European Union." Official Journal of the European Union C 326, 26. Oct. 2012. Web. 16 May 2013. <http://bookshop.europa.eu/en/official-journal-of-the-european-union-c-32626.10.2012-pbFXAC12326/?CatalogCategoryID=wJSep2Ix7TUAAAEwhSwlaWI7>. 
European Parliament. “Motion for a Resolution B7-0523/2011." European Parliament's Intergroup on LGBT Rights, 28 Sept. 2011 Web. 10 February 2012. <http://www.lgbtep.eu/wp-content/uploads/2011/09/RES-20110928-Human-rights-sexual-orientation-andgender-identity-at-the-United-Nations-As-adopted-Provisional.pdf>.

Faure, Gaëlle. "In France, Transsexuals Celebrate a Small Victory." Time World. Time World, 1 March 2010. Web. 4 June 2010.

<http://www.time.com/time/world/article/0,8599,1968767,00.html>.

Foucault, Michel, ed. Herculine Barbin: Being the Recently Discovered Memoirs of a Nineteenth-Century French Hermaphrodite. Trans. R. McDougall. New York: Pantheon, 1980. Gray, John. "The Occupy Movements are the Realists not Europe's Ruling Elites." Guardian. Guardian, 15 Nov. 2011. Web. 23 Feb. 2013.

<http://www.guardian.co.uk/commentisfree/2011/nov/15/occupy-realists-europe-rulingelites>.

Greenberg, Julie A. "Defining Male and Female: Intersexuality and the Collision between Law and Biology." Arizona Law Review 41.2 (1998): 265-328.

Hammarberg, Thomas. Human Rights and Gender Identity. Strasbourg: Commissioner for Human Rights, 2009a.

Hammarberg, Thomas. "The Transgender Rights Deficit." Guardian. Guardian, 5 Sept. 2009b. Web. 6 Sept. 2009. <http://www.guardian.co.uk/commentisfree/2009/sep/05/transgenderhuman-rights-europe>.

Hare, Lauren, et al. "Androgen Receptor Repeat Length Polymorphism Associated with Maleto-Female Transsexualism." Biological Psychiatry 65.1 (2009): 93-6.

Harris, J. President's Guidance No. 1 Evidential requirements for applications under section 11a of the Gender Recognition Act 2004, Letter to the author. Dec. 2005.

Hinkle, Curtis, transl. "Le Provence: Transsexualism Will no Longer be Classified as a Mental Illness in France." Trans News Updates. Lynn Conway, 16 May 2009. Web. 4 Dec. 2012 <http://ai.eecs.umich.edu/people/conway/TS/News/FR/Transsexuality_will_no_longer_be_c lassified_mental_illness_in_France.html>.

Hopkins, Nick. “Bomber Gets Six Life Terms.” Guardian. 1 July 2001: 1.

ILGA-Europe. The Council of Europe Recommendation to Member States on Measures to Combat Discrimination on Grounds of Sexual Orientation or Gender Identity CM/Rec20105: 
A Survey of Progress Towards Implementation in 16 Member States. Brussels: ILGA Europe, 2013.

ILGA-Europe. "Rainbow Europe Map and Index, May 2012." ILGA-Europe. ILGA-Europe, 2012. Web. 5 December 2012. <http://www.ilga-

europe.org/home/publications/reports_and_other_materials/rainbow_europe_map_and_in dex_may_2012>.

International Day against Homophobia and Transphobia. Web. 20. May 2013.

<http://www.dayagainsthomophobia.org>.

International Transgender Day of Remembrance. Web. 20. May 2013.

$<$ http://www.transgenderdor.org/>.

Iovane, Massimo. "The Universality of Human Rights and the International Protection of Cultural Diversity: Some Theoretical and Practical Considerations." International Journal on Minority and Group Rights 14 (2007): 231-62.

Jackson, Julian. Living in Arcadia Homosexuality, Politics, and Morality in France from the Liberation to AIDS. Chicago: U of Chicago P, 2009.

Jones, Jackie. "Human Dignity in the EU Charter of Fundamental Rights and its Interpretation Before the European Court of Justice." Liverpool Law Review 33.3 (2012): 281-300.

Kolyako, Nina. "Czech Republic Is in No Rush to Implement Euro." The Baltic Course. The Baltic Course, 20 May 2010. Web. 12 Feb. 2012. <http://www.baltic-

course.com/eng/baltic_states/?doc=27159>.

Lautmann, Rudiger, Erhard Vismar, and Jack Nusan Porter. Sexual Politics in Nazi Germany: The Persecution of the Homosexuals during the Holocaust. Newton, MA: Spencer P, 1997. Lees, Paris. "Lucy Meadows: Why Her Death Will Not Be in Vain." Guardian. Guardian, 26 March 2013. Web. 17 June 2013.

<http://www.theguardian.com/commentisfree/2013/mar/26/lucy-meadows-death-not-invain>.

Manners, Ian. "The Normative Ethics of the European Union." International Affairs 84.1 (2008): 45-60.

Manners, Ian. "Normative Power in Europe: A Contradiction in Terms?" Journal of Common Market Studies 40.2 (2002): 235-58. 
Ministry of Justice. "Gender Recognition Certificate Statistics April to June 2014." London: Ministry of Justice Statistics Bulletin, 2014.

Mojs, Martijn. "Conflicted Normative Power Europe: The European Union and Sexual Minority Rights." Journal of Contemporary European Research 9.1 (2013): 78-93.

Moor, Louise, and A.W. Brian Simpson. "Ghosts of Colonialism in the European Convention on Human Rights." British Year Book of International Law 76.1 (2005): 121-93.

Nash, Kate. "Human Rights Culture: Solidarity, Diversity and the Right to be Different." Citizenship Studies 9.4 (2005): 335-48.

Pfäfflin, Friedmann, and Astrid Junge. "Sex Reassignment. Thirty Years of International Follow-up Studies After Sex Reassignment Surgery: A Comprehensive Review, 1961-1991." Trans. Roberta Jacobson and Alf Meier. N.p.: International Journal of Transgenderism, 1998. Web. 1 April 2009. <http://209.143.139.183/ijtbooks/pfaefflin/1000.asp>.

Pliny the Elder. The Natural History of Pliny. Trans. and ed. John Bostock and H. T. Riley. Vols. 2 and 3. London: George Bell and Sons, 1890.

Press for Change. Web. 20. May 2013. <http://www.pfc.org.uk/>.

Rametti, Giuseppina, et al. "White Matter Microstructure in Female to Male Transsexuals before Cross-Sex Hormonal Treatment. A Diffusion Tensor Imaging Study." Journal of Psychiatric Research 45.2 (2011a): 199-204.

Rametti, Giuseppina, et al. "The Microstructure of White Matter in Male to Female Transsexuals before Cross-Sex Hormonal Treatment. A DTI Study." Journal of Psychiatric Research 45.7 (2011b): 949-54.

Reis, Elizabeth. “Impossible Hermaphrodites: Intersex in America: 1620-1960." The Journal of American History 92.2 (2005): 411-41.

Rosario, V. "'Is It a Boy or a Girl?' Introduction to Special Issue on Intersex." Journal of Gay and Lesbian Psychotherapy 10.2 (2006):1-7.

Rosin, Michel. “Intersexuality and Universal Marriage.” Law and sexuality 14 (2005): 51-133.

Stop Transpathologization. Web. 20. May 2013. < http://www.stp2012.info/old/en >.

Sweeney, James. "Margins of Appreciation: Cultural Relativity and the European Court of Human Rights in the Post-Cold War Era." International and Comparative Law Quarterly 54.2 (2005): 459-74. 
The Hague Congress. "Political Resolutions." European Movement International. Europe for Citizens Programme, 2008. Web. 20 Nov. 2012

$<$ http://www.europeanmovement.eu/index.php?id=6788>.

Trading Economics. "Portugal Unemployment Rate." Trading Economics, 2013. Web. 15 Feb. 2013. <http://www.tradingeconomics.com/portugal/unemployment-rate>.

Transgender Europe. Web. 20. May 2013. < http://www.tgeu.org>.

Traub, Valerie. The Renaissance of Lesbianism in Early Modern Europe. Cambridge:

Cambridge UP, 2002.

Turner, Lewis, and Stephen Whittle. Transphobic Hate Crime in the European Union. London: Press for Change, 2009.

Turtle, Georgina. Over The Sex Border. London: Gollancz, 1963.

United Nations General Assembly. "Statement on Human Rights, Sexual Orientation and Gender Identity." United Nations General Assembly, 18 Dec. 2008. Web. 7 March 2013. <http://www.unhcr.org/refworld/docid/49997ae312.html>.

United Nations General Assembly. "International Covenant on Civil and Political Rights 1966 No. 14668." United Nations Treaty Series 999 (1976): 171-346.

Waaldijk, Kees. "Standard Sequences in the Legal Recognition of Homosexuality-Europe's Past, Present and Future." Australasian Gay and Lesbian Law Journal 4 (1994): 50-68.

Waaldijk, Kees, et al. Droit conjugal et unions du même sexe: Mariage, partenariat et concubinage dans neuf pays Européens. Paris: Presses Universitaires de France, 2008.

Watson, Katherine, and Stephen Whittle. "Slicing Through Healthy Bodies: The Media of Body Modification." Representing Health: Discourses of Health and IIIness in the Media. Eds Martin King, and Katherine Watson. London: Palgrave, 2004. 104-36.

Whittle, Stephen. "Respectively a Man and a Woman: The Failures of the Gender Recognition Act 2005 and the Civil Partnership Act 2005." Lesbian and Gay Psychology Review: Special Feature; After Wilkinson v Kitzinger. The Future for Same-Sex Marriage 8.1 (2007): 36-45.

Whittle, Stephen. Respect and Equality: Transsexual and Transgender Rights. London: Cavendish Publishing, 2002. 
Whittle, Stephen "Gender Registration: The Requirement of Sterility." in Whittle, Stephen, et al, (2000) "The Problems of Gender Re-Registration." in Home Office, Report of the Interdepartmental Working Group on Transsexual People. London: Home Office, 2000. 41-57

Whittle, Stephen; Turner, Lewis; Combs, Ryan; et al. Transgender EuroStudy: Legal Survey and Focus on the Transgender Experience of Health Care. Brussels: Ilga-Europe, 2008.

Whittle, Stephen, Lewis Turner, and Maryam Al-Alami. Engendered Penalties: Transgender and Transsexual People's Experiences of Inequality and Discrimination, London: Cabinet Office, 2007.

Wilson, Philip, Clare Sharp, and Susan Carr. "The Prevalence of Gender Dysphoria in Scotland: A Primary Care Study." British Journal of General Practice 49.449 (1999): 991-2.

Wyndzen, Madelene. "A Personal and Scientific Look at a Mental Illness Model of Transgenderism." APA Division 44 Newsletter 2004, Spring: 3.

Zhou, Jiang-Ning, et al. "A Sex Difference in the Human Brain and its Relation to Transsexuality." Nature 378 (1995): 68-70. 